\title{
Do the Organizational Choices Really affect Credit Risks? Some Evidence from Italian Banks
}

\author{
Doriana Cucinelli \\ University of Milano-Bicocca \\ Via Degli Arcimboldi, Milan, Italy \\ Federica Ielasi \\ University of Florence \\ Via delle Pandette, Florence, Italy \\ Arturo Patarnello \\ University of Milano-Bicocca \\ Via DegliArcimboldi, Milan, Italy
}

\begin{abstract}
Basel III framework on banking supervision highlights the crucial role of a sound organization in risk management processes. Using a structured survey sent to a group of Italian banks, the study verifies the alignment of organizational choices to sound practices suggested by supervisors. We investigate the role played by the Chief Risk Officer, and the level of integration with the Board of Directors. Our results demonstrate the increasing centrality and strategic responsibilities of the Chief Risk Officer, although with the high level of heterogeneity among banks. Moreover, the increase in integration between governance bodies and the Chief Risk Officer has a positive effect on both bank risk appetite and bank portfolio quality. The main findings suggest that the effectiveness of credit risk management is affected by the spectrum of the responsibilities assigned to the Chief Risk Officer and by the level of integration of risk structures with top governance bodies.
\end{abstract}

Keywords: credit risk management; Chief Risk Officer; banks; survey; credit risk

\section{JEL Code: G21; G32}

\section{Introduction}

During recent decades, enterprise risk management (ERM) has captured the attention of risk management practitioners and academics worldwide. Unlike the traditional "silo-based" approach to corporate risk management, ERM enables firms to benefit from an integrated approach to managing risk, which shifts the focus of the risk management function from primarily defensive to increasingly offensive and strategic goals (Liebenberg and Hoyt, 2003).

In September 2004, the Committee of Sponsoring Organizations of the Treadway Commission (COSO) issued for the first time the Enterprise Risk Management Integrated Framework, to provide a model framework for ERM. The framework defines ERM as "a process, effected by an entity's board of directors, management and other personnel, applied in strategy setting and across the enterprise, designed to identify potential events that may affect the entity, and manage risk to be within its risk appetite, to provide reasonable assurance regarding the achievement of entity objectives" (COSO, 2004). In subsequent years, many organizations implemented this process to increase the effectiveness of their risk management, mainly with the aim of increasing stakeholder-value (Beasley et al. 2005). Proponents of ERM agree that firms choosing to adopt it require a person or a group of persons responsible for the coordination of the ERM program and the communication of goals and results to the board (Daud and Yazid, 2009). In fact, several studies, including Beasley et al. (2005), highlight that the presence of a number of skills among the top management roles like Chief risk officer (CRO), Chief executive officer (CEO) and Chief financial officer (CFO), coupled with the guarantee of board independence, supports the development of ERM in the organizations.

Analyzing risk management specifically in the banking sector is interesting: banks are special firms since their primary business is taking and managing risks, and bank stability is crucial to assure both economic growth and economic stability. The global financial crisis revealed the importance of a sound banks' credit risk management. With reference to risks in traditional commercial banking, as far back as 1999, the Basel Committee (1999) focused on credit risk management practices. It found that many problems arising from credit exposure might be explained by weaknesses in the credit granting and monitoring process. 
In the Committee's view, deficiencies in underwriting and managing market-related credit exposures are significant sources of bank losses, and many credit problems could have been avoided or mitigated through a strong and proper internal credit process. In the last two decades, the Basel Committee and other supervisory authorities have published numerous documents on sound practice in credit risk management, and the impact of credit risk and the role of risk management were also extensively discussed in the recent CRD IV.

With the financial crisis, as a consequence of the sharp increase of non-performing loans, investigating credit risk management (CRM) practice has become very important. CRM is now widely recognized as crucial forbank credit portfolio quality and an effective supervision of credit risk.

Lang and Jagtiani (2010) analyze the role of risk management and corporate governance in the onset of the financial crisis starting from 2007, when dramatic effects of the financial markets on the housing market boom and bust. They pinpoint a failure in the internal control systems, which were unable to identify the concentration of risk in the mortgage market due to opacity of complex structured financial instruments. This suggests a basic failure of risk management and weak corporate oversight. In fact, financial firms lacked effective internal controls, accurate and timely financial and risk reporting to the proper managerial level, and a corporate-wide view of risk or an enterprisewide risk management program.

In the light of the above, CRM has recently become an important component of corporate governance in financial institutions, many of which have appointed the CRO to Board committees as well as the Board of Directors (BoD), thus increasing responsibilities of the role (Cucinelli and Patarnello, 2017; Tchoudep et al., 2018).

The research studies the organizational features of the credit risk management function of Italian banks and the role played by the CRO, evaluating the alignment of banks operational decisions to sound practices specified by international and domestic supervisory authorities, like the Basel Committee, the Financial Stability Board and the Bank of Italy. After analyzing the degree of integration between the CRO and the BoD, we explore the possible connections between this the banks organizational choices and the quality of the credit portfolio.

The study is based on a sample of Italian banks and includes a large number of unlisted institutions, which represent the majority of banks in Italy. The survey investigates a critical period when most Italian banks underwent strong pressure because of a general worsening in credit portfolios and increasing rates of default on their credit exposures as a consequence of the mid-2000financial turmoil.

The paper is organized as follows. Section 2 provides a literature review. Section 3 reports the evolution of regulation of credit risk management. Section 4 discusses the sample and the survey. Section 5 presents the results. The last section presents the conclusions.

\section{Literature Review}

Our paper is at the crossroad of two streams of literature. The first addresses bank risk management practices, and the second focuses on the responsibilities and roles of the main risk managers and risk governance bodies, including the relationship between the BoD and CRO.

With regard to the first strand of literature, risk management in banks became a hot topic during the financial crisis. Despite of the enforcement of Basel 2 regulation, the 2008 financial crisis revealed widespread inefficiency of risk management in banking institutions and the inadequacy of internal models for assessing risk and preventing losses. However, risk management practices have improved and become significantly more sophisticated in recent years. Regulators have put more pressure on the risk management function to enhance the resilience of banking sectors, and it has become crucial for banks to use a large amount of resources to better identify, assess and control risks (Bessis, 2015).

Several authors (Santomero, 1997; Colquitt et al., 1999; Al-Tamimi and Al-Mazrooei, 2007; Matthews, 2011) analyze risk management practices and bank risk management strategies. Colquitt et al. (1999) assess the characteristics and the extent of integrated risk management. They highlight the role of the risk manager and its continuing evolution during the late nineties. The "pure" risk manager was increasingly involved in managing a wider spectrum of risks. More recently, Al-Tamimi and Al-Mazrooei (2007) state that UAE banks are fairly efficient in managing risk: risk identification, risk assessment and analysis are the most influential variables in risk management practices. These authors also pinpoint significant differences between national and foreign banks in UAE at all stages of risk management (assessment, analysis, risk monitoring and controlling). Matthews (2011) based on a sample of 25 Chinese banks, evaluates the performance of the risk management function in terms of contribution to bank profitability. The author uses qualitative data obtained from a questionnaire to create two indexes aimed at measuring the quality of operational and organizational practice in risk management. 
The metrics of risk management operation and organization are used as determinants of bank performance, assuming that both operational and organizational profiles are links in the production chain producing the revenue streams in Chinese banks. Matthews (2011) finds a non-significant direct relationship between the two indexes used in the analysis and ROA, assumed as proxy of performance. However, if a DEA network approached is used, the results show an indirect relationship. Macerinskine and Ivaskeviciute (2014) detect the impact of the financial crisis on credit risk management practices in Lithuania, using a comparative survey of literature supported by a statistical analysis. Macerinskine and Ivaskeviciute (2014) argue that since the financial crisis led to an increase in regulatory burdens such as Basel III and subsequently CRD IV, the additional rules had an important impact on the credit risk management practices. They state that the "improvement of credit risk management is firstly related to following and consolidation of credit risk management principles in everyday operations and strategic management, recognizing the importance of liquidity, improving risk cultures and managing level of risk, redesigning compensation arrangements, improving internal control, learning lesson from outside the financial sector".

In the second strand of literature, concerning risk governance, it is widely recognized that in the banking industry the role played by corporate governance and the $\mathrm{CRO}$ has become crucial and it has been increasingly debated among both practitioners and academics (Fraser \& Henry, 2007; IMA, 2006; Arena et al., 2010).Diamond and Rajan (2009) emphasize that deficiencies in governance mechanisms often explain poor performance of banks during the financial crisis. Kirkpatrick (2009) finds that failures or weaknesses in corporate governance processes are one of the factors that led to the financial crisis. In addition, Acharya et al. (2009) indicate that a strong and independent risk management system is a prerequisite for allowing banks to work in today's risky financial environment.

Suitability and soundness of risk governance have become two of the most important aspects in managing banks. Mongiardino and Plath (2010) suggest that a proper risk governance should comply in at least three important areas: a) a dedicated risk committee should be established at board level; b) the majority of its members should be independent; and c) the Chief Risk Officer should participate in the bank's executive committees. Mongiardino and Plath (2010) conclude that despite regulatory pressures, the risk governance of large banks seems to have improved to only a limited extent since the beginning of the financial turmoil and that there is still ample room for improvement.

Pathan (2009) analyzes the effect of a strong BoD and CEO power on the bank's risk policies, and finds that bank board structure is an important determinant in bank risk-taking. Regulators should thus monitor more intensely those banks where shareholder and manager interests are aligned in order to control their potential for 'excessive risk-taking'. This is particularly important for banks with small and less carefully selected boards, like for example cooperative and savings banks and, generally, unlisted banks (D'Amato, 2018).

Hau and Thum (2009) argue that the financial crisis revealed that the business of banks mostly entails high risks, and conclude that the CRO should probably hold a more important and powerful role within the bank organization. They also indicate that during the financial turmoil, banks with a CRO required to report directly to the BoD performed significantly better than banks with CRO who reported to the CEO. This evidence is consistent with the hypothesis that the effectiveness of the reporting line of the CRO helps to explain the severity of a bank's crisis as the CEO and CRO may have conflicting interests. The results also underline that if the CRO is required to report to the CEO, the risk agenda may not receive the appropriate attention.

Lastly, Ellul and Yerramilli (2013) study the role of risk management in banks by creating a risk management index based on the characteristics of the CRO tasks, such as his/her participation on the Board, remuneration, and participation in executive committees. The index is also based on the risk committee because of members' backgrounds and the number of meetings held. The authors note that banks with a stronger risk management in place before the onset of the financial crisis, i.e. showing a higher risk management index, showed lower risk exposure, a smaller fraction of non-performing loans, a better operating performance and higher annual returns during the financial turmoil. "Overall, findings suggest that a strong and independent risk management system can curtail risk exposures at banks and possibly enhance value, particularly during crisis years" (Ellul and Yerramilli, 2013).

In the light of the previous literature, this study first aims to identify the structure of CRM in the wider context of the risk governance for a group of Italian banks. It focuses specifically on the responsibilities of the CRO and the importance of the function in today's dynamic environment. The second aim is to investigate the relationships between the CRO and other top corporate governance bodies in banks, highlighting the impact of the characteristics of the CRM on bank performance and risk-taking.

The analysis starts from the following hypotheses:

a) Commercial banks and listed banks emphasize a higher collaboration between Board of Directors and CRO than cooperative and savings banks and unlisted banks; 
b) Banks with a higher degree of integration and collaboration between the Board of Directors and the CRO are more integrated, collaborate more and show a lower level of credit risk and risk appetite.

\section{Supervisory perspective and the effects on CRM}

The need for effective governance and internal control mechanisms to monitor the effect of risk taking was widely felt from the 2007-08 turmoil onwards as a consequence of a general increase in vulnerability of banking institutions. In many countries, the weakness of the banking industry can be seen in prevailing bank business models, in the decreasing quality of loan portfolios.

This general trend changed the relative importance of both aims and levers of risk supervision, as clearly shown by the evolution of supervisory rules and industry practices.

In the 1990s and early 2000s, supervisors mainly focused on strengthening the prudential framework and the stability of the banking system through capital adequacy rules, but since 2010 a renewed set of rules concerning risk governance and internal control has been introduced. These include Basel Committee, 2010; CEBS, 2010; and EBA, 2011. In addition, despite the complexity of the 2007-08 turmoil, regulators clearly stated that the credit risk was by far the most important risk faced by banks.

One of the significant innovations introduced by the EBA in the field of risk management is the key role given to the internal control system. EBA underlines the advantages of a three-stage action plan:

- risk management has the strategic responsibility of identifying, measuring and managing bank risks;

- the internal control function ensures the efficiency and effectiveness of banking activity, especially for those businesses that may generate risks;

- finally, Internal Audit reviews internal processes and the quality of the organizational design.

With regard to the role of risk management, the EBA suggests a vertical structure, in which the actions under the responsibility of the Internal Audit function require the intervention of the credit committee composed of members selected within the Board.

Furthermore, the activities of risk management should involve the CRO and the credit risk function. The CRO is required to be horizontally integrated with other second-level control functions and should inform and adequately train the staff of the unit acting as a conduit toward the different control functions at the same time.

The changing relationships between supervisors and the professional environment over the last decade can be seen in the following evidence:

- an increasing diversity of the business mix among banks, reflecting the use of different business models combining a number of different risk portfolios;

- a lower effectiveness of internal models and metrics in assessing business risks and estimating capital requirements;

- a plurality of sources of risk and traditional risks arising in different ways. In credit risk, in fact, different risk profiles reflect financial innovation, market deals and the amount of cross border transaction with huge counterparty risks.

The EU Regulation issued in 2013, aimed at implementing the Basel Committee framework of December 2010, was intended to promote a more solid and resilient banking system, partly by revisiting the discipline on capital adequacy and, at the same time, highlighting the crucial role of a sound organisation in risk management processes ${ }^{1}$.

The Regulation(CRD IV) stated a new capital requirement for banks, and specifically addressed the use of internal rating models in credit risk management. CRD IV expresses a preference for IRB models for those banks managing credit risks of significant level and complexity, but suggests using the standardized approach only when the credit risk is relatively low. At the same time, CRD IV underlines the importance for supervisors of monitoring the lending processes in order to ensure well-defined criteria for approving, amending, renewing and refinancing credit.

Additionally, the 2013 Principles of the Financial Stability Board (FSB), aimed at ensuring the effectiveness of the Risk Appetite Framework (RAF), especially for credit institutions classified as Systemic Institutions (SIFI), stress the responsibilities of the $\mathrm{BoD}$ and top management, i.e., the $\mathrm{CEO}, \mathrm{CFO}$, and $\mathrm{CRO}$, in designing a solid risk governance system. The FSB Principles recognize a clear internal framework on bank risks as suitable for strengthening bank risk culture and positively influencing the implementation of sound risk management practices. For this purpose, the Financial Stability Institute proposed in 2015 the creation of a risk committee within the BoD, acting independently of other committees.

\footnotetext{
${ }^{1}$ Regulation (EU) n. 575/2013 (CRR) and Directive 213/36/EU (CRD IV), both incorporated in the domestic 285/2013 Banca d'Italia Regulation $\left(22^{\circ}\right.$ update).
} 
It also suggested that the CRO regularly attends the board meetings and is appointed to enhance the knowledge of the board members regarding risk management issues. The same principles are stated in 2015 Basel Committee Guidelines on corporate governance. The Guidelines aim at implementing sound risk management systems in banks and ensuring the independence and expertise of the CRO.

It is most importantly the third Annual Report published in 2017 by the FSB "Implementation and Effects of G20 Financial Regulatory Reforms" which outlines the principles of an effective RAF. The report defines role and responsibilities of both board and senior management, and focuses on the implementation of the principles in the context of SIFI. It also recommends that the principles be applied to other smaller institutions with a proportional approach and in coherence with the complexity of their business.

The report also stresses the tasks assigned to the whole board in specifying the content of the bank's RAF and in ensuring its logical connection with its short and long-term strategies. It also specifies that the board, in coordination with the CRO, the CFO and the business lines, bears the crucial role of turning RAF guidance into current operations, specifically when risk limits must be explicitly defined.

The tasks of the board include ensuring the following:

- implementation of the risk appetite statement proposed by senior management through approving risk limits for every business line and legal entity;

- adequate staff, in terms of number and expertise, for risk management and internal audit functions in order to guarantee that operations comply with the approved RAF;

- Coherence of IT architecture with the goals assigned to risk management for identifying, measuring and assessing the risks.

The principles also outline the responsibilities of the CRO and of the other members of the top management. Briefly, the $\mathrm{CRO}$ is required:

- to identify together with the top management suitable risk limits for the business lines and legal entities in coherence with the risk appetite of the bank. This substantially defines the bank's risk appetite in line with supervisory requirements;

- to assure the integrity of risk metrics for risk monitoring purposes;

- to guarantee effective and complete reporting to the board on business risks and the adherence of single business units to the risk appetite stated by the governance.

In a supervisory perspective, the function of the CRO is strategic as s/he plays the key role in the bank's organizational framework of linking the subjects responsible for risk governance and strategies and the operational units assessing risk exposure and making risk taking decisions.

For these reasons, academic debate has been enriched with technical contributions from regulators and banking institutions discussing best practice for CRM functioning and the role of the CRO.

The Financial Services Authority (FSA) in the recently published internal "Check List for Credit Risk Management" indicates a number of organizational features of an appropriate architecture for bank CRM systems.

Although the FSA recognizes that CRM systems differ according to strategy and business mix, it underlines the need for a single explicit framework for CRM operations to be used throughout an organization. Moreover, FSA Guidelines highlight the importance of monitoring CRM actions by a Director specifically appointed to this task and supported by internal auditors who periodically assess the compliance of CRM decisions with internal rules.

Looking at the organizational structure of CRM, the FSA recommends separating the CRM processes and the management of non-performing loans into different units.

In many cases, the professional environment itself underlines the advantages of establishing formal rules in CRM processes and focuses on the centrality of the organizational design for ensuring the effectiveness of risk taking decisions in lending.

One such contribution is the Senior Supervisors Group document (2009), which suggests disseminating risk management rules across the entire organization and involving board members together with the Internal Audit in monitoring activities. This practice should reflect bottom-up, rather than top-down, risk management. In other words, information should flow from lower level to the top management, and should be derived from current operational processes, for an efficient risk strategy at corporate level.

Finally, from the practitioner perspective, in order to properly allocate managerial and staff expertise, allocation into a separate unit of NPL management appears to be effective. 
This brief overview concerning regulatory and practitioner statements on CRM can be summarized as follows:

- Because of differences between banks in terms of size, markets and business mix it is expected that the approach to CRM will differ between institutions. However, as a general trend, risk governance processes and organizational rules are becoming increasingly important compared to risk metrics and models;

- As in other areas requiring a framework of prudential rules, supervision authorities in banking show an implicit preference for a dialectic relationship with board members and top management. This entails respective responsibilities in risk taking decisions and partially regaining discretionarily in banking supervision;

- At the same time, this behavior appears to recognize theincreasing importance of best practice in risk management implemented by the professional environment.

In the light of the above, we now assess the state-of-the art of the organizational design and functioning of CRM systems and their integration with governance bodies for a group of Italian banking institutions.

\section{Sample and Methodology}

\subsection{Sample}

The study initially involved a sample of 151 Italian banks, investigated through a questionnaire. They comprise 82 cooperative, 43 commercial, 2 investments and 24 savings banks. Only 20 banks are listed, with the remaining ones (131 banks) unlisted or delisted.

Banks were used for the sample if total assets in 2016 were higher than one billion euro.

Only 26 institutions responded to the survey. However, these account for $60 \%$ of total assets of the Italian banking system at the end of 2017. The banks in the sample are mainly commercial banks focusing on lending, and have an average ratio of gross loans to total assets of $65 \%$.Banks with a different core business were excluded from the analysis, as credit risk management is considered not to be an important function when lending is not the bank's core business.

The final sample includes 2 unlisted saving banks, 14 cooperative banks - 3 listed and 11 unlisted - and 10 commercial banks -7 listed and 3 unlisted. ${ }^{2}$

\subsection{Survey description}

The main purpose of the study is to examine the CRM systems and practices in Italian banks, specifically looking at the role of the CRO and at the connections of CRO functions with governance structures. A descriptive survey research approach was used.

We developed a structured questionnaire based on the supervisory guidelines on the issues under investigation, as summarized in the Basel's Credit Risk Management Principles (2000), in the Italian domestic regulation update to 2013 (Circolare Bancad' Italia 263 of 2006, 15 ${ }^{\text {th }}$ update 2013) and in the EBA Risk Appetite Framework Guidelines (2013). Through the questionnaire, we collected data about the organization of CRM, CRM practices and the RAF in our sample.

The questionnaire includes questions with multiple choice answers, short open answers and answers based on a 7pointLikert scale. We chose a 7-point scale, because it is more sensitive than the traditional 5-pointscale which does not provide sufficient sensitivity to detect small but significant differences (Jaeschke and Guyatt, 1990; Diefenbach et al., 1993). In addition, Krosnick and Fabrigar (1997) find that a curvilinear pattern emerged in their review, proving that scales with 5-7 points are more reliable than scales with either fewer points or more points. Typically, the rule of thumb is to prefer a 5-point scheme for unipolar scale (i.e. with assessments like "never" -"always" at the extremes) and a 7-point one for bipolar scale (i.e. with statements like "strongly disagree" and "strongly agree" at the extremes) (Maitland, 2013).In our study, we used a 7-pointbipolar scale, following Finstad (2010) who finds that a 7-point scale is more adequate for electronically-distributed and/or unsupervised questionnaires. In fact, a 7-point scale is more effectivewhen the answers provided are markedly concentrated on positive or negative judgments.

The surveyfirst examines the responsibilities of the CRO, verifying the alignment of the CRO responsibilities to the sound practices suggested by supervisory authorities, and, secondly, the integration between the CRO and bank top corporate governance bodies. To measure the integration, on the basis of methodologies developed by Matthews (2011), and Ellul and Yerramilli (2013), we define two risk management indexes:

a) the first measures the role of theBoDin CRM practices and evaluates the information flows between the BoD and the risk management units;

\footnotetext{
${ }^{2}$ Investment banks and the financial companies are not included, although they replied to the survey, because we believe that the credit risk is specific to commercial, savings and cooperative banks.
} 
b) the second measures the presence of the CRO in the corporate governance bodies, in terms of participation at BoDand risk committee meetings, as well as the reporting activities required.

After implementing the two indexes, we scale the responses on a 10 points scale, with the first index accounting for 5 points and the second for the remaining 5 points. We obtain an integrated risk management index - the CRMGOV which we compare with a number of credit risk indicators, in order to analyze the relationship between CRM practices with risk appetite and risk-taking behaviors of the banks in the sample.

\section{Results}

\subsection{The role of the CRO}

In this section we show the results of the survey carried out with specific reference to the role of CRO and the specific responsibilities assigned to the function.

In order to verify the presence of a sound credit granting process and the use of adequate processes aimed at measuring, managing and monitoring credit risk, the analysis sought to verify the CRO's tasks in the banks examined. The organizational criteria published by the FSB in November 2013 were taken into consideration when drafting the questions on this topic in the questionnaire.

In detail, we verified the level of agreement of the respondents with regard to the presence of the following CRO responsibilities in their bank:

Q1.The definition and development of the bank's Risk Appetite, in co-operation with the BoD and the CFO, in line with company strategy and supervisor expectations;

Q2.The integration of the measurement techniques used to verify the alignment of the bank's actual risk profile with its stated Risk Appetite;

Q3.The definition and approval, alongside the CEO and the CFO, of appropriate risk limits for the business lines and legal entities of the banking group, according to its Risk Appetite;

Q4.The monitoring that the risk limits assigned to the business lines and to the legal entities within the group are in line with the Risk Appetite;

Q5.The reporting of situations in which the risk moves close to or exceeds the approved Risk Appetite;

Q6.The intervention aimed at ensuring effective and timely countermeasures if the risk exceeds the stated limits;

Q7.The monitoring of single exposure performance and the assessment of operating choices regarding non-performing loans (coherence of classifications, appropriateness of provisions and adequacy of the recovery process).

Overall, the results suggest that banks are only partially aligned to the guidelines provided by supervisors in terms of appropriate tasks of the CRO. On the 7-point Likert scale, the average value for the suitability of CRO responsibilities in line with supervisory suggestions is close to 5 . This outcome means that the respondents agree to an extent, but not fully, that the specified responsibilities are in fact reflected in the tasks assigned to their CRO.

The CRO for the banks in the sample is primarily responsible for evaluating the performance of individual exposures and for assessing that the non-performing exposures are correctly classified and supported by proper provisioning or an adequate recovery process $(\mathrm{Q} 7)$. Less frequently, the responsibility of the CRO in the surveyed banks involvesthe definition and approval of appropriate risk limits for the business lines and legal entities of the group (Q3). These tasks are probably more often assigned to the $\mathrm{CEO}$ or the $\mathrm{CFO}$, while the role of the $\mathrm{CRO}$ is still more focused on monitoring and reporting tasks in the majority of the banks in our sample.

However, the variability of the answers on the responsibilities of the CRO is very high, and shows that there are important differences in the organization of CRM processes among the banks analysed.

In order to highlight the causes of these differences, we considered bank characteristics in more detail, distinguishing between commercial banks and cooperative/saving banks, as well as between listed and unlisted banks. The latter segmentation is useful both for capturing differences arising from the size of the banks and to outline the effects of potential constraints relating to risk management quality when a bank acts on currently regulated financial markets.

As shown in Table 1, several differences among groups of banks are statistically significant, as tested by measuring the differences between averages (T-test). For example, a significant difference between listed and unlisted banks appears in the task related to the definition and approval of risk limits for the business lines and the legal entities of the group (Q3) and also in the monitoring that these risk limits are in line with the risk appetite of the banking group (Q4).

Comparing commercial banks and cooperative/saving ones, significant differences can be found considering the responsibility for monitoring that the risk limits assigned to the business lines and legal entities of the banking group are in line with its Risk Appetite (Q4), and the responsibility for reporting situations in which the risk exceeds or nears the approved Risk Appetite (Q5). 
Table 1: The responsibilities of the CRO

\begin{tabular}{|l|c|c|c|c|}
\hline & $\begin{array}{c}\text { Q1. The responsibility } \\
\text { for the development and } \\
\text { definition, with the } \\
\text { Board of Directors and } \\
\text { Chief Financial Officer } \\
\text { (CFO), of the bank's } \\
\text { Risk Appetite, in line } \\
\text { with company strategy } \\
\text { and supervisor } \\
\text { expectations }\end{array}$ & $\begin{array}{c}\text { Q2. The } \\
\text { responsibility for } \\
\text { the integration of } \\
\text { the measurement } \\
\text { techniques used to } \\
\text { verify the } \\
\text { alignment of the } \\
\text { bank's actual risk } \\
\text { profile compared } \\
\text { to its Risk } \\
\text { Appetite }\end{array}$ & $\begin{array}{c}\text { Q3. The responsibility } \\
\text { for the definition and } \\
\text { approval, alongside the } \\
\text { CEO and the CFO, of } \\
\text { appropriate risk limits } \\
\text { for the business lines } \\
\text { and legal entities of the } \\
\text { banking group, in line } \\
\text { with its Risk Appetite }\end{array}$ & $\begin{array}{c}\text { Q4. The } \\
\text { responsibility for } \\
\text { monitoring that } \\
\text { the risk limits } \\
\text { assigned to the } \\
\text { business lines } \\
\text { and legal entities } \\
\text { of the banking } \\
\text { group are in line } \\
\text { with its Risk } \\
\text { Appetite }\end{array}$ \\
\hline $\begin{array}{l}\text { Commercial } \\
\text { banks }\end{array}$ & 5,22 & 5,56 & 5,11 & $5,00^{*}$ \\
\hline $\begin{array}{l}\text { Cooperative and } \\
\text { savingsbanks }\end{array}$ & 5,06 & 5,00 & 4,53 & $4,76^{*}$ \\
\hline Listedbanks & 5,70 & 5,70 & $5,30^{*}$ & $5,50^{*}$ \\
\hline Unlistedbanks & 4,75 & 4,88 & $4,38^{*}$ & $4,44^{*}$ \\
\hline Total Average & 5,12 & 5,19 & 4,73 & 4,85 \\
\hline Stand Dev & 1,78 & 2,00 & 1,78 & 1,76 \\
\hline
\end{tabular}

\begin{tabular}{|l|c|c|c|c|}
\hline & $\begin{array}{c}\text { Q5. The } \\
\text { responsibility for } \\
\text { reporting situations } \\
\text { in which the risk } \\
\text { exceeds or nears the } \\
\text { approved Risk } \\
\text { Appetite }\end{array}$ & $\begin{array}{c}\text { Q6. The responsibility } \\
\text { for intervening in order } \\
\text { to guarantee effective } \\
\text { and timely } \\
\text { management in } \\
\text { situations where the } \\
\text { risk exceeds the } \\
\text { declared limits }\end{array}$ & $\begin{array}{c}\text { Q7. The responsibility } \\
\text { for monitoring the } \\
\text { performance of } \\
\text { individual exposures and } \\
\text { for assessing the } \\
\text { operating choices } \\
\text { regarding non- } \\
\text { performing loans }\end{array}$ & Average of the \\
7 \\
Commercial \\
banks
\end{tabular}

Note: Table reports the average responses at the questions that refer to the responsibilities of Chief Risk Officer. Asterisks denote T-test significance at: $* * * \mathrm{p}<0.01, * * \mathrm{p}<0.05, * \mathrm{p}<0.1$

\subsection{The CRMGOV index: the integration between the CRO and the top governance structures}

After examining the most common tasks of the CRO within the banks examined, we analysed the answers concerning the degree of integration of CRM structures in the corporate governance mechanisms, and specifically the interactions with the Board of Directors. In detail, we investigated the role of the Board of Directors in supervising and affecting the credit risk processes, the information flows between the Board of Directors and the risk management unit, and lastly the positioning of the CRO within the bank's top management.

In order to assess the potential impact of the level of integration between the CRM and corporate governance on risks taken by the banks, we built an index based on the questionnaire answers, as suggested by Matthews (2011), and Ellul and Yerramilli (2013). The index measures the level of involvement of the Board of Directors in the CRM processes, as well as the frequency of presence of the CRO in the top governance structures of the banks examined.

The index, named CRMGOV, ranging between 0 and 10, makes it possible to assign up to 5 points in assessing the role of the Board of Directors in the CRM and the consequent information flows (first part of the index), and assigns 5 other points when the presence of the CRO in the corporate governance structures is detected (second part of the index). 
The 5 points concerning the first part of the index are assigned to each bank according to the answers given to specific questions that reflect the supervisors' guidelines on the role of the Board of Directors in CRM processes. In particular, we asked whether:

Q8. The Board of Directors determines the strategies and policies of the CRM;

Q9. The Board of Directors reviews and updates CRM strategies and policies at least once a year;

Q10. The Board of Directors evaluates and approves CRM proceedings;

Q11. The bank has a system of continuous CRM processes assessment and the Board of Directors and top management are currently informed about the outcome;

Q12. The bank's RAF is defined mainly through top down processes (from the Board of Directors to the staff);

Q13. The bank's RAF is defined mainly through bottom up processes (from the staff to the Board of Directors);

Q14. The CRO periodically reports to the Board on the bank's actual risk profile compared to the defined Risk Appetite;

Q15. The bank's CRO promptly informs the Board and the CEO of any situation in which the risk limits are breached to such an extent that the bank faces the risk of exceeding the declared Risk Appetite, exposing it to an unstable situation.

The answers to these questions were collected on a 7-point Likert scale. The average measures were then rescaled onto the range $0-5$, in order to contribute to the overall value of the index.

Using the average score obtained by the banks examined, it is possible to identify a proper level of integration between the Board of Directors and the CRM in our sample. The average on the Likert scale shows a score of more than 5 with the consequent attribution of 3.66 points out of 5 to the first part of the CRMGOV index.

Examining individual answers to questions Q8-Q15 above, we note that the degree of agreement is minimal compared to the definition of the RAF in bottom-up processes (Q13). On the other hand, there is better alignment regarding the role of the Board of Directors in revising and updating CRM strategies and policies at least once a year (Q9).

As shown in Table 2, the highest degree of involvement of the Board of Directors in the CRM choices can be observed in listed banks. In particular, using the T-test, we found the most significant differences between average score comparing listed and unlisted institutions when we examined the CRO's reporting activity to the Board on the bank's actual risk profile compared to the defined Risk Appetite (Q14).

The second part of the CRMGOV index is related to the presence and role of the CRO in topcorporate governance structures. The additional 5 points of the CRMGOV index were thus assigned according to the answers given to the following questions:

Q16. Does the CRO participate in the Board of Directors?

Q17. Is the CRO a member of the Executive Committee appointed by the Board of Directors?

Q18. Does the CRO participate in the Risk Committee set up within the Board of Directors?

Q19. If the CRO participates in the Risk Committee, does he/she have decision-making responsibilities?

Q20. Is the CRO required to report to a top governance body?

The score for every question is 0 if the respondent answers negatively or in the absence of the relative organizational position in the bank, and the score are 1 if the answer is positive.

Table 2: The Role of the Board of Directors in the CRM and consequent information flows

\begin{tabular}{|l|c|c|c|c|}
\hline & $\begin{array}{c}\text { Q8. The Board of } \\
\text { Directors } \\
\text { determines the } \\
\text { strategies and } \\
\text { policies of the } \\
\text { CRM }\end{array}$ & $\begin{array}{c}\text { Q9. The Board of } \\
\text { Directors reviews and } \\
\text { updates e CRM } \\
\text { strategies and } \\
\text { policies at least once } \\
\text { a year }\end{array}$ & $\begin{array}{c}\text { Q11. The Board of } \\
\text { Directors evaluates } \\
\text { and approves CRM } \\
\text { proceedings }\end{array}$ & $\begin{array}{c}\text { Q11. The bank has a } \\
\text { system of continued } \\
\text { CRM processes } \\
\text { assessment: the Board of } \\
\text { Directors and Top } \\
\text { Management are } \\
\text { informed of the outcome }\end{array}$ \\
\hline Commercial banks & 5.33 & 6.00 & 5.56 & 5.33 \\
\hline $\begin{array}{l}\text { Cooperative and } \\
\text { savingsbanks }\end{array}$ & 5.00 & 5.59 & 5.35 & 4.76 \\
\hline Listedbanks & 5.70 & $6.20^{*}$ & 5.80 & 5.40 \\
\hline Unlistedbanks & 4.75 & $5.44 *$ & 5.19 & 4.69 \\
\hline Total Average & 5.12 & 5.73 & 5.42 & 4.96 \\
\hline Stand Dev & 1.53 & 1.51 & 1.63 & 1.61 \\
\hline
\end{tabular}




\begin{tabular}{|l|c|c|c|c|}
\hline & $\begin{array}{c}\text { Q12. The bank's } \\
\text { RAF is defined } \\
\text { partly through top } \\
\text { down processes } \\
\text { from the Board of } \\
\text { Directors to the } \\
\text { staff) Directors }\end{array}$ & $\begin{array}{c}\text { Q13. The bank's } \\
\text { RAF is defined } \\
\text { partly through } \\
\text { bottom up processes } \\
\text { from the staff to } \\
\text { the Board of } \\
\text { Directors }\end{array}$ & $\begin{array}{c}\text { Q14. The CRO } \\
\text { periodically reports } \\
\text { to the Board on the } \\
\text { bank's actual risk } \\
\text { profile compared to } \\
\text { the defined Risk } \\
\text { Appetite }\end{array}$ & $\begin{array}{c}\text { Board and informs the } \\
\text { situation in which the risk } \\
\text { limits are violated to such } \\
\text { an extent that the bank } \\
\text { faces the risk of } \\
\text { exceeding the declared } \\
\text { Risk Appetite, exposing it } \\
\text { to an unstable situation }\end{array}$ \\
\hline Commercial banks & 5.22 & 4.33 & 5.56 & 6.11 \\
\hline $\begin{array}{l}\text { Cooperative and } \\
\text { savingsbanks }\end{array}$ & 4.53 & 3.76 & 5.24 & 5.47 \\
\hline Listedbanks & 5.00 & 4.50 & $6.20^{* *}$ & 6.10 \\
\hline Unlistedbanks & 4.63 & 3.63 & $4.81^{* *}$ & 5.44 \\
\hline Total Average & 4.77 & 3.96 & 5.35 & 5.69 \\
\hline Stand Dev & 1.56 & 1.97 & 2.08 & 1.83 \\
\hline
\end{tabular}

Note: Table reports the average responses given to the questions that refer to the role of the Board of Directors in the credit risk management and the information flows. Asterisks denote significance at:*** $\mathrm{p}<0.01, * * \mathrm{p}<0.05,{ }^{*} \mathrm{p}<0.1$

Overall, in the least common situation in the sample (only for two unlisted banks) the CRO is part of the executive committee appointed by the Board of Directors (Q17). In about half of the sample, the CRO is a member of the Risk Committee established within the Board of Directors (with a score relatively higher for listed companies) (Q18). With reference to Q20, in ten banks the CRO reports directly to the Board of Directors, in one case to the executive committee and in one bank to the CEO.

As shown in Table 3, the business structure or status of business is a statistically significant parameter to distinguish the banks where CRO joins the Risk Committee, with or without decision-making responsibilities (Q18 and Q19), and those institutions where the CRO is required to report to a top governance level (Q20). Neither cooperative banks nor savings banks declare that the CRO is involved in the Risk Committee with decision-making responsibilities.

Table 3: The CRO in the corporate governance structures

\begin{tabular}{|l|c|c|c|c|c|}
\hline & $\begin{array}{c}\text { Q16. Does the } \\
\text { CRO } \\
\text { participate in } \\
\text { the Board of } \\
\text { Directors? }\end{array}$ & $\begin{array}{c}\text { Q17. Is the CRO } \\
\text { amber of the } \\
\text { Executive } \\
\text { Committee } \\
\text { appointed by the } \\
\text { Board of } \\
\text { Directors? }\end{array}$ & $\begin{array}{c}\text { Q18. Does the } \\
\text { CRO participate } \\
\text { in the Risk } \\
\text { Committee set } \\
\text { up within the } \\
\text { Board of } \\
\text { Directors? }\end{array}$ & $\begin{array}{c}\text { Q19. If the CRO } \\
\text { participates in the } \\
\text { Risk Committee, } \\
\text { does he/she have } \\
\text { decision-making } \\
\text { responsibilities? }\end{array}$ & $\begin{array}{c}\text { Q20. Is the } \\
\text { CRO required } \\
\text { to report to a } \\
\text { top } \\
\text { governance } \\
\text { body? }\end{array}$ \\
\hline Commercial banks & 0.44 & 0.11 & $0.67 *$ & $0.44^{* * *}$ & $0.67 *$ \\
\hline $\begin{array}{l}\text { Cooperative and } \\
\text { savingsbanks }\end{array}$ & 0.41 & 0.06 & $0.35^{*}$ & $0.00^{* * *}$ & $0.35^{*}$ \\
\hline Listedbanks & 0.50 & 0.00 & $0.70^{* *}$ & 0.20 & 0.50 \\
\hline Unlistedbanks & 0.38 & 0.13 & $0.31^{* *}$ & 0.13 & 0.44 \\
\hline Total Average & 0.42 & 0.08 & 0.46 & 0.15 & 0.46 \\
\hline Stand Dev & 0.50 & 0.27 & 0.51 & 0.37 & 0.51 \\
\hline
\end{tabular}

Note: Tables reports the average responses at the questions that refer to the CRO and the corporate governance structure. Therefore, the relationship between the CRO and the other corporate governance bodies. Asterisks denote significance at: *** $\mathrm{p}<0.01, * * \mathrm{p}<0.05, * \mathrm{p}<0.1$

As shown in Table 4, the groups of banks examined show big differences in the overall value of CRMGOV index. In particular, for the first part of the index, the status of listed company is the parameter that most clearly distinguishes the level of integration between the Board of Directors and the CRM structure. In the second part of the index,however, the business structure is what most clearly distinguishes between banks in the sample: commercial banks show the highest scores for the presence of the CRO in corporate governance structures, and cooperative credit banks and savings banks show lower scores. 
Table 4: CRMGOV index

\begin{tabular}{|l|c|c|c|}
\hline & $\begin{array}{c}\text { CRMGOV index } \\
- \text { first part }- \\
\text { Integration Board of } \\
\text { Directors-CRM } \\
\text { average on 5-scale) }\end{array}$ & $\begin{array}{c}\text { CRMGOV index } \\
- \text { second part }- \\
\text { presence of the CRO } \\
\text { in corporate } \\
\text { governance structures }\end{array}$ & $\begin{array}{c}\text { CRMGOV index }- \\
\text { total }\end{array}$ \\
\hline Commercial banks & 3.88 & $2.33^{* *}$ & $6.21^{* * *}$ \\
\hline $\begin{array}{l}\text { Cooperative and } \\
\text { savingsbanks }\end{array}$ & 3.55 & $1.18^{* *}$ & $4.72^{* * *}$ \\
\hline Listedbanks & $4.01^{* *}$ & 1.90 & $5.91^{*}$ \\
\hline Unlistedbanks & $3.44^{* *}$ & 1.38 & $4.82^{*}$ \\
\hline Total Average & 3.66 & 1.58 & 5.24 \\
\hline
\end{tabular}

Note: Table reports the average of the integrated risk management index. Asterisks denote significance at:*** $\mathrm{p}<0.01, * * \mathrm{p}<0.05, * \mathrm{p}<0.1$

\subsection{The integration between $\mathrm{CRO}$ and governance bodies and the effects on banks credit risks}

Lastly, we investigate the relationship between the CRMGOV index and some risk indicators, with specific reference to credit risk. In particular, we analyzed two proxies of credit portfolio quality - the NPL to gross loans ratio and the loan loss reserve to non-performing loans - and a measure of the bank risk appetite, proxied by the risk weighted assets to total assets ratio. Figures 1, 2 and 3 illustrate the results and provide a measure of the correlation between the CRMGOV index and risk characteristics of the banks.

The descriptive statistics, shown in Table 5, underline that, on average, our sample is composed by banks with a core business in lending (65.46\% of gross loans to total assets). There are however differences among banks and there is clear divergence between the minimum and maximum values of the ratio. The two proxies of the credit portfolio quality show a similar variability, although the standard deviation in these cases is lower than in the previous case (gross loans to total assets ratio). Finally, with reference to the risk appetite, the average ratio is lower than $50 \%$, although the bank with the highest proportion of RWA shows a value of $65 \%$.

Table 5 Descriptive statistics

\begin{tabular}{cccccc}
\hline Variable & Obs & Mean & St. Dev & Min & Max \\
\hline RWA/TA & 26 & 48.706 & 11.579 & 28.372 & 65.418 \\
LLR/GL & 26 & 8.132 & 5.219 & 0.398 & 21.221 \\
NPL/GL & 26 & 16.836 & 8.7216 & 2.202 & 34.281 \\
\hline
\end{tabular}

Note: Table reports the descriptive statistics of bank specific characteristics in term of credit risk and risk appetite ratios

The results describing the credit portfolio quality (Figures1 and 2) show a negative relationship between the CRMGOV index and both the NPL ratio and the coverage ratio. This suggests that banks with a higher index (higher integration between CRM and corporate governance) achieve a better credit portfolio quality, in terms of NPL proportion, and in terms of a lower coverage ratio. The correlation between the CRMGOV index and the two ratios is negative in both cases $\left(-0.2759\right.$ between CRMGOV index and LLR over GL and $-0.3505^{*}$ between CRMGOV index and NPL over GL).

Figure 1 Relationship between CRMGOV and NPL over Gross Loans ratio

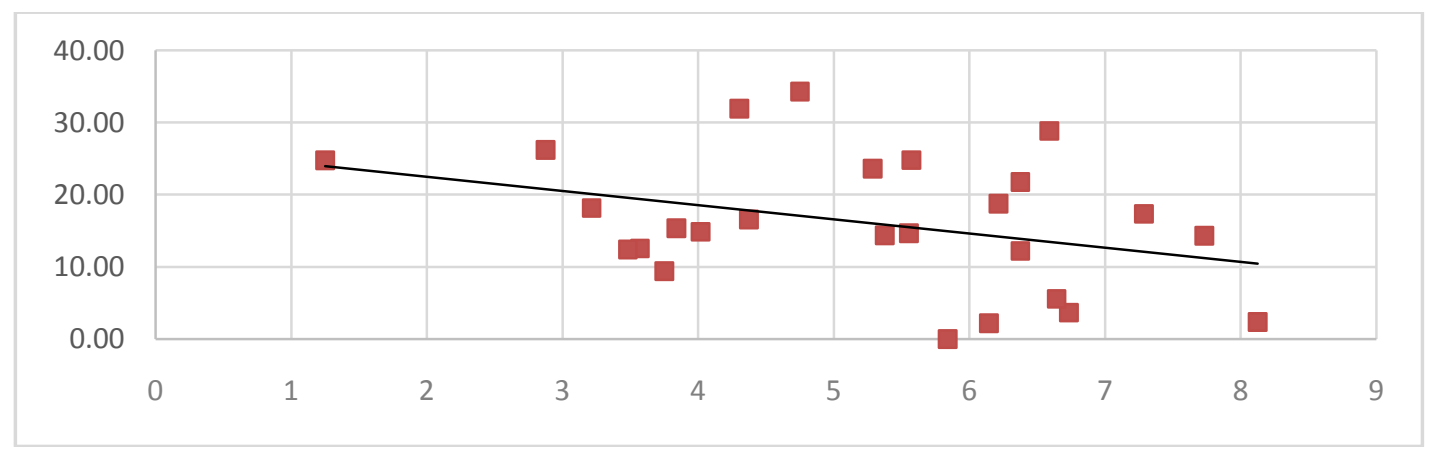

Note: Figure shows the relationship between the CRMGOV and the bank credit risk. The bank credit risk is proxied by the non-performing loans over total gross loans. The CRMGOV is the integrated risk management index. 
Figure 2 Relationship between the CRMGOV and the loan loss reserve over non-performing loans ratio

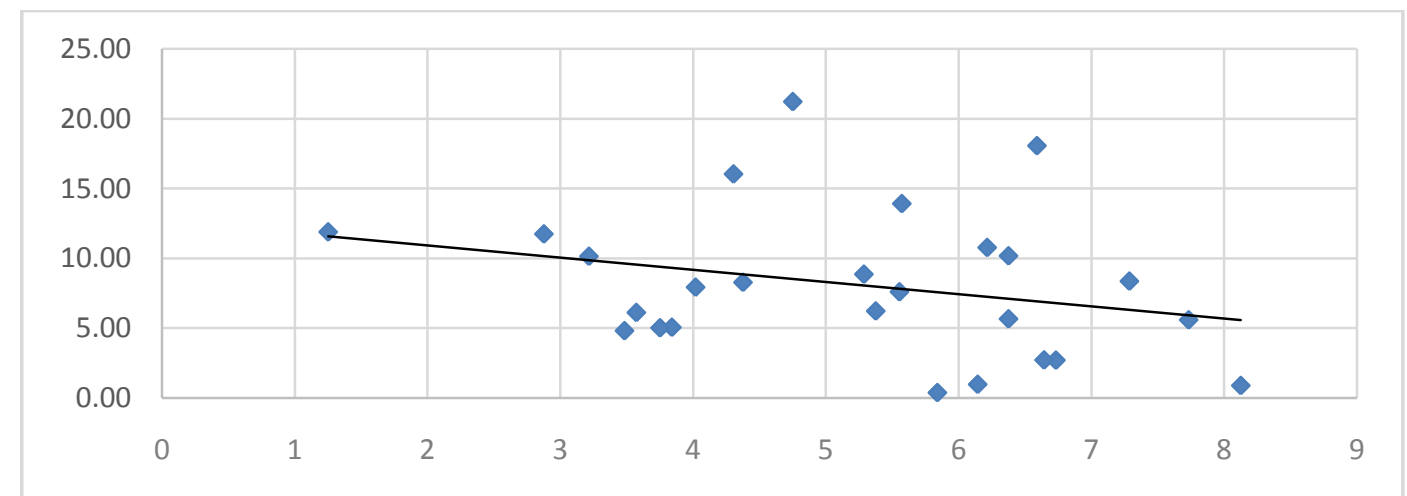

Note: Figure shows the relationship between the CRMGOV and the bank credit risk. The bank credit risk is proxied by the loan loss reserve over non-performing loans, which is the common label coverage ratio. The CRMGOV is the integrated risk management index.

However, if we look at the significance of the correlation, we observe a degree of statistical significance (90 per cent) only in the case of the relationship between CRMGOV and NPL_GL, while no statistical significance is detected in the correlation between the index and the LLR ratio. Our findings thus suggest that the higher the integration between credit risk management and corporate governance structure, the higher the credit portfolio quality measured by the NPL ratio.

Lastly, looking at bank risk appetite, a negative correlation can be observed between the CRMGOV index and the RWA density (-0.3998 with a statistical significance of 90\%). Figure 3, in fact, highlights the negative relationship between the two variables investigated. The evidence suggests that banks with a higher integration between CRM and corporate governance show a lower risk appetite. This may be due to an improved attitude of banks towards credit management and reducing the credit risk associated with lending activity.

Figure 3 The relationship between CRMGOV and bank risk appetite

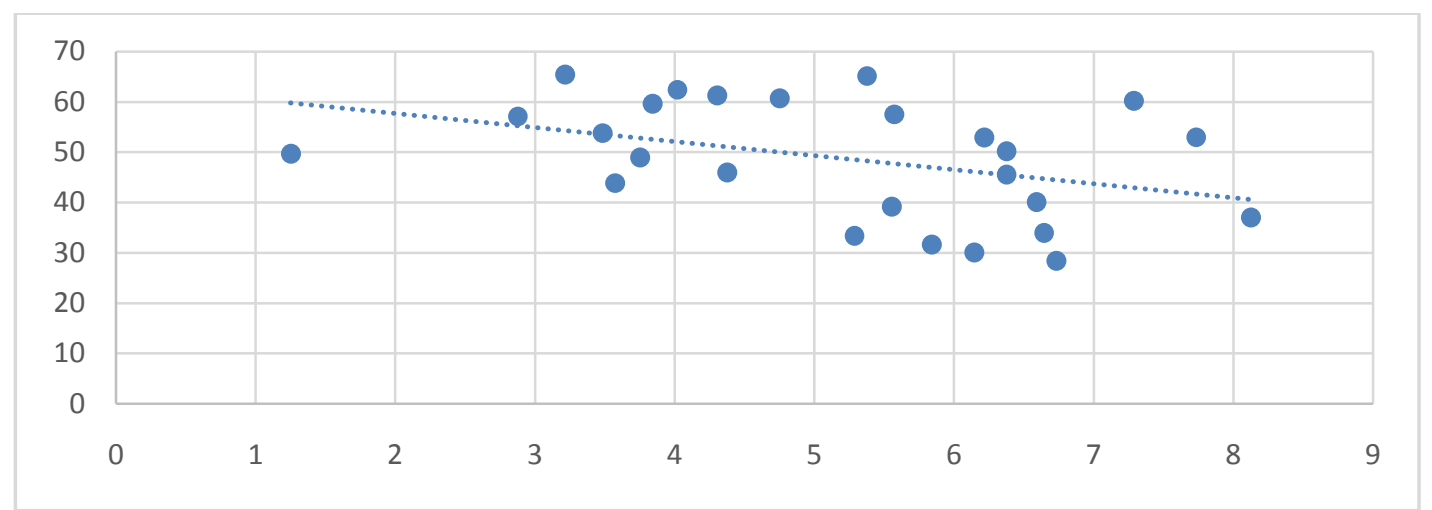

Note: Figure shows the relationship between the CRMGOV and the bank risk appetite. The bank risk appetite is proxied by the risk weighted assets over total assets. The CRMGOV is the integrated risk management index.

\section{Conclusions}

The 2007-08 financial crisis highlighted deficiencies in bank risk management and the lack of effectiveness of the internal risk models. In particular, during recent decades, the quality of many bank credit portfolios has worsened and banks have been forced to deal with this deterioration. At the same time, regulators have increased pressure to enhance the resilience of the banking industry, risk management processes have been considerably improved, and credit risk management practices have become more sophisticated.

Focusing on a sample of 26 Italian banks and using the information obtained through a structured survey sent during the first half of 2016, our analysis identifies the characteristics of the credit risk management function and the role played by CRM unit in fostering the alignment of operational decisions and processes with the practices indicated by the Basel Committee, the Bank of Italy, and the Financial Stability Board. The study also analyzes the relationship between bank corporate governance and the role of the chief risk officer. 
Finally, the study focuses on possible connections between credit risk management and bank governance, and the relevance of these for the quality of the credit portfolio. Looking at the role and the responsibilities of CRO in banks, we observe that alignment with supervisory guidelines is not complete, and there remain important areas still to be implemented or improved.

It appears for example that CRO currently carry out tasks mainly involving monitoring and control rather than playing a strategic and proactive role. This is particularly true for the cooperative and saving banks, as well as for unlisted banks.

The level of integration of the $\mathrm{BoD}$ with the CRM structures is quite good. In particular, at least once a year Boards carry out reviews and updates related to CRM strategies and policies. On the other hand, the definition of the RAF through bottom-up processes is not adequately widespread, probably partly because of the size of many of the banks examined. We find in fact that information and decision-making flows on risk management issues follow mostly topdown mechanisms.

With reference to the degree of communication and integration between the Board and the risk management structures, as could be expected, information flows are adequate and more continuous in listed banks.

Generally, in most of the banks examined, the CRO reports directly to the Board, and this certainly strengthens integration between the top management and the risk management units. However, the CRO typically does not sit on the executive committee, whereas he/she is usually part of the risk committee, often without decision-making responsibilities. This confirms that the primary focus of CRO role is on operational tasks, particularly in banks which are not limited responsibility companies ( $\mathrm{SpA}$ in Italy).

The differences in the sample made it interesting to verify whether the level of integration of the CRM in corporate governance might influence bank risk appetite and the amount of credit risk actually faced.

In the last section of our analysis, focusing on the relationships between the integration of credit risk management in corporate governance and bank credit risk, we observe a positive relationship between the level of integration and the credit portfolio quality and a negative relationship between the level of integration and bank risk appetite. This suggests that banks with a higher integration between the $\mathrm{BoD}$ and the $\mathrm{CRO}$ are more effective in managing credit risk and in selecting their customers, as they experience a lower percentage of non-performing loans and lower risk density in their portfolios.

In the light of these results, we agree with supervisors that metrics and techniques of risk management are important but that the adequacy of processes and internal controls are equally so. In fact, encouraging banks to integrate their governance with risk management procedures, and, specifically in our study, with credit risk management procedures, can improve the procedures themselves and increase the credit portfolio quality.

Although focused on a restricted sample of banks, the study suggests a methodological approach that can be easily replicated for evaluating the role of the organization choices in risk-taking and management. We are confident that our research, which is based on one specific country, can be extended to other systems, and will serve as a basis for future studies on the evolution of the role and responsibilities of the Chief risk officer. The future role in fact will need to move from an operating and controlling role to a more strategic position with a higher level of interconnection with top governance structures.

Our findings are that first, organization matters in the definition of risk appetite and the level of risks actually faced by banks. The effectiveness of credit risk management is affected by the spectrum of the responsibilities assigned to risk managers and by the level of integration of risk structures with top governance bodies. More generally, this suggests that organizational variables are as important as the efficiency of internal models. It is confirmed by the increasing attention by supervisors to the quality of processes and the correct identification of responsibilities in risk-taking decisions. The operational environment has in fact become more in tune with proper risk management practices.

Secondly, our survey demonstrates the increasing centrality and strategic responsibilities of the CRO, although with a high level of differences between banks.

Finally, our results underline how the degree of integration of credit risk structures with the governance bodies and the quality of the bottom-up information flows are crucial in achieving a balanced exposure to credit risk.

\section{References}

Acharya Viral V., Cooley T., Richardson M. and Walter I. (2009), "Manufacturing Tail Risk: A Perspective on the Financial Crisis of 2007-2009." Foundations and Trends R in Finance 4: 247-325. 
Al-Tamimi H. A. H. and F. M. Al-Mazrooei (2007), "Banks' risk management: a comparison study of UAE national and foreign banks", The Journal of Risk Finance 8: 394-409.

Arena, M., Arnaboldi, M., Azzone, G.(2010), “The organizational dynamics of enterprise risk management”. Accounting, Organizations and Society 35 (7): 659-675.

Banca d'Italia (2013), “Directive 213/36/UE del parlamento europeo e del consiglio (CRD IV)".

Banca d'Italia (2013), “Disposizione di vigilanza per le banche, Regulation 285/2013”.

Basel Committee (1999), "Principle for the management of credit risk. Consultative paper issued by the Basel Committee on Banking Supervision", Bank for international settlements.

Basel Committee (2010), "Basel III: a global regulatory framework for more resilient banks and banking system”, Bank for international settlements.

Basel Committee (2015), “Corporate governance principles for banks”, January 9, Bank for international settlements.

Beasley M.S., Clune R., Hermanson D.R. (2005), "Enterprise risk management: An empirical analysis of factors associated with the extent of implementation". Journal of Accounting and Public Policy, 24 (6): 521-531.

Bessis J. (2015), “Risk Management in Banking”, $4^{\text {th }}$ edition, Wiley, ISBN 978-1-118-66021-8

Committee of European Banking Supervisors (2010), "High-level principles for risk management”, February.

Colquitt, L. L., Hoyt, R. E. and Lee, R. B (1999), “Integrated Risk Management and the Role of the Risk Manager”. Risk Management and Insurance Review, vol. 2:43-61.

Colquitt, J. (2007), "Credit Risk Management: How to Avoid Lending Disasters \& Maximize Earnings”,3rd Edition, McGraw-Hill.

COSO (2009), "Strengthening enterprise risk management for strategic advantage", available at (www.coso.org).

Cucinelli D., Patarnello A. (2017), "Bank credit risk management and risk culture" (edited by Alessandro Carretta, Franco Fiordelisi, Paola Schwizer). Palgrave.

D'Amato A. (2018), "Risk-Taking in Cooperative Banks: Do Board Characteristics Matter?" International Journal of Business and Social Science, November, Vol. 9 (11): 80-90.

Daud W. N. and Yazid A. S. (2009), “A conceptual framework for the adoption of enterprise risk management in government-linked companies”. International review of business research papers, vol. 5 (5): 229-238.

Diamond Douglas W. and RaghuramRajan(2009), "The Credit Crisis: Conjectures about Causes and Remedies," NBER Working Papers 14739.

Ellul, Andrew, and Yerramilli Vijay Stronger (2013), "Risk Controls, Lower Risk: Evidence from U.S. Bank Holding Companies", Journal of Finance 68:1757-1803.

EuropeanRegulation (2013), "Regolamento UE n. 575/2013 del parlamento europeo e del consiglio del 26 giugno 2016 relativo ai requisiti prudenziali per gli enti creditizi e le imprese di investimento (CRR)", EuropeanRegulation EU.

European Banking Authority (2011), “Guidelines on Internal Governance, GL 44, September.

Fraser I., W. Henry (2007) "Embedding risk management: structures and approaches", Managerial Auditing Journal, Vol. 22 (4): 392-409, https://doi.org/10.1108/02686900710741955

Faser, J. and Simkins, B. J. (2010), “Enterprise Risk Management: today’s Leading Research and Best Practices for Tomorrow's Executive", Hoboken, New York, NY: John Wiley \& Sons.

Financial Stability Board (2014), “Guidance on Supervisory Interaction with financial institutions on risk culture. A framework for assessing risk culture".

Financial Stability Board (2013), "Principles for an effective risk appetite framework", November.

Finstad K. (2010), “The Usability Metric for User Experience. Interacting with Computers”, vol. 22, pp. 323-327.

Hau, H., and M. P. Thum (2010), "Subprime crisis and the board (in-)competence: Private vs. public banks in Germany",CESifo Working Paper 2640.

Kirkpatrick, G. (2009), "The corporate governance lessons from the financial crisis". Financial market trends, ISSN 1995-2864, OECD.

Lang W. and Jagtiani J. (2010), “The mortgage and financial crises: the role of credit risk management and corporate governance”. Atlantic Economic Journal, vol. 38 (2): 123-144.

Liebenberg A. P. and Hoyt R. E. (2003), “The determinants of enterprise risk management: evidence from the appointment of chief risk officer. Risk management and insurance review", vol. 6 (1): 37-52.

Matthews, K. (2013), "Risk management and managerial efficiency in Chinese banks: A network DEA framework Omega", 41:207-215.

Macerinskiene, I., Ivaskeviciute, L., and Railiene, G. (2014), "The financial crisis impact on credit risk management in commercial banks". KSI transactions on knowledge society, 7:5-16.

Mongiardino, A. and C. Plath (2010), “Risk governance at large banks: Have any lessons been learned?". Journal of Risk Management in Financial Institutions 3:116-123.

Pathan S. (2009), "Strong boards, CEO power and bank risk-taking”. Journal of Banking and Finance, Vol. 33: $1340-1350$.

Santomero, A. M. (1997), "Commercial Banking Risk Management: an Analysis of the Process", USA: The Wharton Financial Institutions Center.

Senior Supervisors Group (2009), "Risk Management Lessons from the global banking crisis of 2008”,document, October.

Tchouadep E.C., Mburu H.K., Githui T. (2018), "Attitude to Risk of Credit Managers and Efficiency of Credit Management in Real Estate Investment Trusts in Kenya”. International Journal of Business and Social Science,May, Vol. 9 (5): $133-140$. 